УДК 342.9

DOI https: / / doi.org/10.32837 / yuv.v0i4.1977

\author{
А. Чуб, \\ кандидат юридичних наук, \\ здобувач кафедри адміністративного та господарського права \\ Запорізького національного університету
}

\title{
КЛАСИФІКАЦІЯ СУБ'ЄКТИВНИХ ПУБЛІЧНИХ ПРАВ ПРИВАТНОЇ ОСОБИ
}

Постановка проблеми. Як свідчить історія виникнення та становлення наукової категорії «суб'єктивні публічні права», $з$ моменту початку активного й глибокого догматичного ii відпрацювання теоретики встигли запропонувати безліч іï визначень і класифікацій, що свідчить про багатогранність і наукомісткість цього феномена [1, с. 31]. I це не дивно: адже, беручи до уваги поліаспектність взаємодіі індивідів і держави та іï органів, що виступають як публічна влада, можна впевнено припустити, що досліджувані права надзвичай різноманітні як за сферою суспільних відносин, яких вони стосуються, так і за власним юридичним змістом.

Взагалі метод класифікації виступає одним із найважніших методів наукового пізнання, осмислення та описання закономірностей оточення, а також формою пізнання, базою емпіричного знання, засобом впорядкування знань. Метод класифікації в науці використовується з метою систематизації та організації знань, репрезентації знань у надійному й зручному для огляду, розпізнавання та зіставлення вигляді, відбиття або встановлення порядку речей; представлення знань; використання знань; опосередкованого надання знань.

Класифікацією вважають розподіл предметів певного роду на класи відповідно до найсуттєвіших ознак, притаманних предметам такого роду, що відрізняють їх від пред- метів інших родів, водночас кожен клас посідає в системі, яка склалася, певне постійне місце й своєю чергою поділяється на підкласи. Класифікування ж $є$ процесом приведення певної предметної галузі в систему, встановлення відносин спорідненості між цими предметами й групування їх у кластери - таксони за ступенем спорідненості. Тобто класифікація як результат класифікування - мережа таксонів різного рангу, в якій знаходить своє місце кожний об'єкті з досліджуваної предметної галузі [2, с. 252].

3 зазначеного випливає, що класифікація в адміністративно-правовому дослідженні не може й не повинна відігравати роль яскравої ілюстрації досліджуваного матеріалу або данини науковій традиції; це передусім серйозний гносеологічний інструмент, що виконує функції систематизації знання, описання та пояснення досліджуваного об'єкта, засади конструювання наукових теорій або впорядкування реальної дійсності.

Ступінь наукової розробки проблеми. Розгляд сучасної проблематики класифікації суб'єктивних публічних прав спирається на грунтовну теоретичну базу, створену вітчизняними й зарубіжними науковими підходами до дослідження цієї тематики. Тому, беручись до теми класифікації суб'єктивних прав у публічній сфері, дослідник у галузі адміністративного права нині має обов'язково ставити собі питання, 
3 якою саме метою він збирається ii здійснити. У нашому випадку це узагальнення масиву знань і пошук правдивих пояснювальних (теоретичних) моделей розподілу суб'єктивних публічних прав, які можуть бути продуктивно екстрапольовані на весь масив досліджуваних прав і дадуть уявлення про ї різноманітність та однорідність, про загальні й специфічні їхні характеристики.

Метою наукової статті $€$ здійснення класифікації суб'єктивних публічних прав приватної особи.

Виклад основного матеріалу. Базову класифікацію суб'єктивних публічних прав у свій час запропонував ще Г. Еллінек у праці «Система суб'єктивних публічних прав» [3]. Обираючи підставу для розподілу суб'єктивних публічних прав на окремі класи, вчений спирався на думку, що суб'єктивні публічні права по суті $є$ можливістю домагань приватної особи до органів публічної влади, а рівень цих домагань визначений правовим статусом особи - конкретним їі становищем стосовно держави. Згідно із цими міркуваннями Еллінек виділив чотири різновиди правового статусу й відповідні категорії суб'єктивних публічних прав:

1) пасивний статус особи (status passivus) характеризується станом підкорення індивіда органам влади, йому відповідають виключно обов'язки приватних осіб стосовно держави. 3 одного боку, тут ідеться про свободу публічної влади й несвободу приватної особи; з іншого, на думку Еллінека, підкорення приватної особи державі розповсюджується лише на дозволений об'єктивним правом простір, тобто кожне домагання держави до приватної особи повинно мати правове підгрунтя. Іншими словами, суб'єктивне право, що відповідає пасивному статусу, полягає в обмеженості обтяження приватної особи публічно-правовими обов'язками сферою ї̈ залучення до державного правопорядку; незаконне обтя- ження особи обов'язками виступає підставою для оскарження дій публічної влади;

2) активному статусу особи (status activus) відповідають політичні права, що містять права на участь в організації та діяльності публічної влади, у формуванні державної волі (виборчі права, право петицій, свобода спілок, зібрань тощо). Тут вчений демонструє, як реалізація нормативно закріплених можливостей викликає до життя активну громадянську позицію;

3) негативний статус (або свободний статус) (status negativus sive status libertatis) корелює 3 правами приватних осіб на свободу від держави, від втручання органів публічної влади у сферу наданої приватним особам свободи - $з$ правами на недоторканність особи, житла, імені, на свободу переміщень тощо. Статус свободи, або негативний статус (зазначимо, що слово «негативний» тут позбавлено семантичного відтінку чогось поганого й спирається на розуміння негації як протилежності чомусь, у нашому контексті свободи як протилежності примусу) означає вільний від втручання держави стан приватної особи. У силу такого становища приватна особа може претендувати на відміну всіх розпоряджень публічної влади, що порушують іï свободу, всіх адміністративних актів, що обмежують іiі права або створюють перешкоди до їх здійснення. Тобто це сфера абсолютного самовизначення індивіда, в яку держава взагалі не має права втручатися. Формальними характеристиками цієї сфери, на думку Еллінека, $€$, по-перше, індивідуальні цілі й приватні інтереси, по-друге - виключна дія принципу свободи волевиявлення;

4) позитивний статус особи (status positivus) означає, що приватна особа 3 метою реалізації власних інтересів має право користуватися державними інститутами. Водночас сама держава зобов'язана не тільки не супере- 
чити здійсненню цих інтересів, але й у позитивний спосіб сприяти йому. До цієї групи прав Еллінек відносив насамперед право на судовий захист індивідуальних інтересів, порушених органами публічної влади [4, с. 73-75].

Пропонуємо проілюструвати цю класифікацію прикладами суб'єктивних публічних прав, що існують у сучасному українському публічно-правовому полі. По-перше, розглянемо політичні суб'єктивні права, які призначені на підтримку й забезпечення реалізації основних політичних прав, закріплених у ст. ст. 36-39 Конституції України: права на свободу об’єднання в політичні партії та громадські організації для здійснення та захисту своїх прав і свобод і задоволення політичних, економічних, соціальних, культурних та інших інтересів; права брати участь в управлінні державними справами, у всеукраїнському й місцевих референдумах, вільно обирати й бути обраними до органів державної влади й органів місцевого самоврядування; права збиратися мирно, без зброї та проводити збори, мітинги, походи й демонстрації, про проведення яких завчасно сповіщаються органи виконавчої влади чи органи місцевого самоврядування [5].

Слід зазначити, що практичне забезпечення реалізації права на свободу об'єднання відбувається шляхом реалізації суб'єктивних публічних прав, визначених Законом України «Про громадські об'єднання», яким закріплено права й порядок створення та припинення діяльності об'єднання громадян, право на членство в громадському об'єднанні [6], яким відповідає обов'язок органу публічної влади (Мінюсту та його територіальних органів, виконавчих органів сільських, селищних, міських Рад народних депутатів) щодо легалізації об'єднання через внесення його до Єдиного державного реєстру юридичних осіб, фізичних осіб - підприємців і громадських формувань [7]. Право брати участь у державному управлінні реалізується завдяки таким суб’єктивним публічним правам, як право вільно обирати й право бути обраним, що відповідають адміністративно-правовим статусам виборця та кандидата на виборну посаду й закріплені п. 2 ст. 6 Виборчого кодексу України [8].

Складна ситуація спостерігається у сфері реалізаціі права на мирні зібрання, де, на відміну від попередніх прикладів, відсутня нормативно закріплена модель поведінки приватної особи чи дій суб'єктів публічної влади, потрібних для реалізації законного інтересу в проведенні мирного зібрання, тобто легітимізоване суб'єктивне публічне право. Насправді дозвіл на реалізацію цього права фактично виданий Конституцією, проте самої моделі реалізації, закріпленої правовою нормою, в чинному законодавстві немає. Умовою реалізації цього конституційного права виступає вимога «завчасного сповіщення місцевих органів виконавчої влади чи органів місцевого самоврядування», а ось конкретні терміни цього завчасного сповіщення не визначив навіть Конституційний Суд України, обмежившись указівкою на «прийнятні строки» [9]. Ця ситуація ускладнилась протизаконними рішеннями деяких місцевих органів влади щодо ухвалення власних «порядків проведення мирних зібрань» зі встановленням вимог і строків, які заперечувалися громадянами в судах; врешті-решт судові спори перетнули український кордон і вийшли на рівень Європейського суду з прав людини (далі ЄСПЛ). ЄСПЛ у справі «Вєрєнцов проти України» виніс рішення від 11 квітня 2013 року, в якому встановив, що в Україні не існує жодних правових підстав для обмеження права на мирні зібрання [10].

На наш погляд, вкрай необхідне нормативне закріплення можливої поведінки приватної особи в разі організації мирних зібрань та участі в них, тобто суб'єктивного публічного права, на рівні закону України 
«Про мирні зібрання». Прийняття цього акта має супроводжуватися обов'язковим закріпленням у ньому як суб'єктивних публічних прав приватних осіб на мирні зібрання, так і обов'язків органів публічної влади, що забезпечують реалізацію цього права. Це сприятиме спрощенню ситуації у сфері реалізації конституційного права на мирні зібрання та водночас дозволить покращити імідж України як демократичної держави на міжнародній арені.

Суб'єктивні публічні права приватних осіб на свободу від держави можна проілюструвати таким прикладом, як право на інформацію, що містить вільне ії використання й розповсюдження. Суб'єктивні публічні права в цій сфері - право на вільний обмін інформацією, свобода вираження поглядів і переконань - закріплюються Законом України «Про інформацію» [11], а ті, що цим правам кореспондують, обов'язки публічної влади щодо забезпечення доступу до необхідної інформації - Законом України «Про доступ до публічної інформації» [12].

Право на користування державними інститутами в розумінні Г. Еллінека означає право на судовий захист; сучасним українським законодавством передбачено здійснення адміністративного судочинства, яке забезпечує можливість захисту прав та інтересів приватних осіб від порушень із боку суб'єктів, наділених владними повноваженнями. Мало того, згідно з принципом інстанційності, закріпленим Законом України «Про судоустрій і статус суддів» [13], вітчизняна судова система організована в спосіб, що забезпечує право на перегляд рішення суду нижчої інстанції судом вищої інстанції. Цей спосіб - інстанційність як принцип організації судової системи - виступає додатковим чинником обмеження можливої владної сваволі у відносинах із приватними особами, посилюючи ефективність судового захисту прав та інтересів останніх [14]. Тобто суб'єктивне публічне право на судовий захист від порушень інтересів приватних осіб суб'єктами публічної влади має декілька (три) рівнів реалізації.

Узагальнюючи результати розгляду класифікації Г. Еллінека, можна дійти висновку, що вчений вважав наділеними суб'єктивними публічними правами активний, негативний і позитивний правові статуси приватної особи; в його теоретичній моделі першому відповідають політичні права, другому - права на свободу від держави, тобто на невтручання держави, третьому - права на користування державними інституціями задля досягнення власних інтересів (у розумінні Еллінека - право на судовий захист, в пізніших розробках - також право на позитивні послуги з боку держави). Пасивний статус індивіда в цій моделі супроводжувався виключно обов'язками приватної особи. Надалі ця класифікація була допрацьована О. Маєром і його прибічниками, завдяки аргументації яких до числа суб'єктивних публічних були віднесені публічно-речові права [1], приклад яких ми також пропонуємо розгледіти детальніше.

Так, до об'єктів суб'єктивних публічно-речових прав серед іншого належать і водні ресурси нашої держави, адже згідно зі ст. 13 Конституціï земля, іï надра, атмосферне повітря, водні й інші природні ресурси, які знаходяться в межах території України, природні ресурси ї континентального шельфу, виключної (морської) економічної зони є об'єктами права власності Українського народу [5]. Суб’єктивне публічне право безоплатного й безперешкодного водокористування закріплено ст. 47 Водного кодексу України [8], однак на практиці відбувається загальне встановлення огорож і споруд, які блокують доступ громадян до рекреаційних водойм, забороняючи риболовлю, купання та відпочинок біля річки чи моря. 
Для виправлення ситуації в плані реалізації зазначеного суб'єктивного права було ухвалено Закон України «Про внесення змін до деяких законодавчих актів України щодо забезпечення безперешкодного доступу громадян до узбережжя водних об'єктів для загального водокористування», яким закріплено обов'язок органів публічної влади сприяти реалізації права на безоплатне й безперешкодне водокористування: на органи місцевої державної адміністрації чи виконавчі органи сільської, селищної чи міської ради покладається завдання здійснення контролю за забезпеченням безперешкодного й безоплатного доступу громадян до узбережжя водних об'єктів та островів для загального водокористування відповідно до закону [16]. У такому випадку, коли право приватної особи підкріплюється обов'язком органу публічної влади, й можна говорити про суб'єктивне публічне право.

Взагалі у вітчизняному теоретичному просторі адміністративно-правової науки питанню класифікації суб'єктивних публічних прав приділено досить уваги. Водночас легко помітити, що класифікація Г. Еллінека виступає базисом багатьох сучасних наукових розробок, що підкреслює ii наукову значущість та евристичну ефективність.

Так, власне бачення розподілу пропонує В.К. Колпаков для адміністративних прав (так у науковій літературі іноді називаються суб'єктивні права громадян у відносинах з органами управління [17], тобто суб'єктивні публічні права):

а) соціально-економічні, які стосуються основ життя людей і становлять базу правового статусу громадян: право на працю, матеріальне забезпечення, право на освіту, на охорону здоров'я;

б) політичні права й свободи права на свободу думки, совісті, релігіi, зібрань, мітингів, демонстрацій, об'єднання в політичні партіі; право вносити пропозиції до державних органів і критикувати недоліки, оскаржувати в суді діі посадових осіб; право на судовий захист. Сюди також належать право обиратися та бути обраним у ради будь-якого рівня; право на користування досягненнями культури, свободу наукової, технічної, художньої творчості;

в) особисті права й свободи - права, пов'язані $з$ виконанням громадянами дій, спрямованих на задоволення особистих потреб [18, с. 158-159].

Схожий погляд демонструють автори підручнику «Адміністративне право України», обираючи як критерій розподілу чинник змісту прав i поділяючи адміністративні права громадян на три такі групи:

1) участь у державному управлінні й соціально-політична активність: право на державну службу, внесення пропозицій, одержання необхідної інформації та документів у встановленій формі, проведення зборів, мітингів, демонстрацій, створення громадських об'єднань чи входження в них тощо;

2) одержання допомоги від відповідних компетентних організацій: право на медичну, санітарно-епідеміологічну допомогу, безкоштовне користування благами (бібліотеками, парками тощо), користування транспортом одержання платних та інших послуг;

3) права, що захищаються в адміністративному (адміністративна скарга, адміністративно-юрисдикційне провадження) або в судовому порядку (адміністративний позов).

Взаємодіючи з органами виконавчої влади, вважають учені, громадяни реалізують передусім такі суб'єктивні права: на участь в управлінні; на об'єднання; на проведення мітингів, демонстрацій, зборів; на особисті або колективні звернення до державних органів; на свободу й особисту недоторканність; на недоторканність житла; на пересування; на інформацію; на відшкодування шкоди, 
заподіяної незаконними діями державних організацій, а також посадових осіб під час виконання ними службових обов'язків [19].

Подібну диференціацію прав спостерігаємо в іншій науковій праці, де адміністративні права умовно поділяють на такі групи:

1) права, пов'язані з участю громадян в управлінні;

2) права, пов'язані із задоволенням громадянами матеріальних, культурних та інших потреб;

3) права, пов'язані 3 можливістю захисту своїх прав і свобод [20, с. 52-55].

Висновки. Таким чином, у ході аналізу наукових підходів щодо класифікації суб'єктивних публічних прав нам вдалося встановити, що досліджувані права є розгалуженою системою, що об'єднує досить різні за змістом, сферою використання, нормативно-правовою базою публічно-правові феномени. Якщо ж намагатися вибудувати внутрішню ієрархію цієї системи, то в основу, на наш погляд, слід закласти розподіл суб'єктивних публічних прав на права, пов'язані з участю в публічному управлінні (умовно «публічно-управлінські права»); права, пов'язані з реалізацією законних інтересів у соціальній, культурній, економічній, екологічній тощо сферах («соціокультурні права»); права, пов'язані із захистом і відновленням порушених органами публічної влади прав («захисні права»). Саме ця диференціація має стати стовбуром класифікаційного дерева; так, публічно-управлінські й соціокультурні права можуть розгалужуватися за суб'єктом права - на загальні, спеціальні й індивідуальні; за ступенем можливості реалізації права - на абсолютні й відносні; за галузевою належністю нормативної бази - на адміністративні й змішані тощо; за змістом можливої дозволеної правом поведінки - на права-дії та права-вимоги. Інша ситуація подальший розподіл захисних суб'єк- тивних публічних прав, які можуть бути класифіковані за критерієм правових норм, що їх регулюють, на адміністративно-процесуальні й адміністративно-процедурні.

У науковій статті визначено критерії класифікації суб’єктивних публічних прав приватної особи. Розглянуто, щзо здійснення класифікації суб'єктивних публічних прав обтрунтовуе їхне розуміння як розгалуженої системи, що об'єднує досить різні за змістом, сферою використання, нормативно-правовою базою публічно-правові феномени. Наголошено, що метод класифікаціï виступає одним із найважніших методів наукового пізнання, осмислення та описання закономірностей навколишнього середовища, а також формою пізнання, базою емпіричного знання, засобом впорядкування знань. Досліджено, щзо метод класифікаиіi в науцу використовується з метою систематизаціï та організаціï знань, репрезентаиії знань у надійному й зручному для огляду, розпізнавання та зіставлення вигляді, відбиття або встановлення порядку речей; представлення знань; використання знань; опосередкованого надання знань. З’ясовано, що побудова внутрішньої ієрархї изієі системи трунтується на розподілі суб'єктивних публічних прав на права, пов'язані з участю в публічному управлінні (умовно «публічно-управлінські права»); права, пов'язані з реалізацією законних інтересів у соціальній, культурній, економічній, екологічній тощо сферах («соціокультурні права»); права, пов'язані із захистом $i$ відновленням порушених органами публічної влади прав («захисні права»). Обгрунтовано, що в межах системи суб'єктивних публічних прав виділяються такі групи прав, як публічно-управлінські й соціокультурні, шо можуть розгалужу- 
ватися. За правочинним суб'єктом виділено загальні, спеціальні й індивідуальні суб'єктивні публічні права; за ступенем можливості реалізації права - абсолютні й відносні; за галузевою належністю нормативної бази - адміністративні й змішані тощо; за змістом можливої дозволеної правом поведінки права-дії та права-вимоги.

Ключові слова: класифікація, критерії, об'єкт, публічно-управлінські правовідносини, система, суб'єкт.

Chub A. Classification of subjective public rights of a private person

The scientific article defines the criteria for classifying the subjective public rights of an individual. It is determined that the implementation of the classification of subjective public rights justifies their understanding as a branched system that combines quite different in content, scope, legal framework public law phenomena. It is emphasized that the method of classification is one of the most important methods of scientific knowledge, understanding and describing the laws of the environment, as well as a form of knowledge, the basis of empirical knowledge, a means of organizing knowledge. It is emphasized that the method of classification in science is used to systematize and organize knowledge, representation of knowledge in a reliable and easy to view, recognize and compare the form, display or establish the order of things; presentation of knowledge; use of knowledge; indirect provision of knowledge. It was found that the construction of the internal hierarchy of this system is based on the distribution of subjective public rights to rights related to participation in public administration (conditionally "public administration rights"); rights related to the realization of legitimate interests in social, cultural, economic, environmental, etc. spheres ("socio-cultural rights"); rights related to the protection and restoration of rights violated by public authorities ("protective rights"). It is substantiated that within the system of subjective public rights there are such groups of rights as: public administration and socio-cultural rights can be branched. General, special and individual subjective public rights are allocated for the authorized subject; according to the degree of possibility of realization of the right - to absolute and relative; by industry affiliation of the regulatory framework - administrative and mixed, etc.; according to the content of possible behavior permitted by law - on rights-actions and rightsrequirements.

Key words: classification, criteria, object, public-administrative legal relations, system, subject.

\section{Література}

1. Винницкий A.В. Учение о субъективных публичных правах бл «государственноуправленческого подхода» в науке. Право и политика. 2018. № 12. С. 27-40.

2. Понкин И.В. Классификация как метод научного исследования, в частности в юридической науке. Вестник Пермского университета. Юридические науки. 2017. Bып. 37. C. 249-259.

3. Еллинек Г. Система субъективнахх публичных прав / пер. со 2-го нем. изд-я ; под ред. А.А. Рождественского. Санкт-Петербург, Москва : Изд-во Освобождение, 1913. URL: https:// viewer. rusneb.ru/ru/000199_000009_004014568?p age $=1$ \& rotate $=0$ \& theme $=$ white .

4. Зелениов А.Б. Субъективное публичное право : учебное пособие. Москва: Российский университет дружбы народов, 2012. 148 с.

5. Конституція України : Закон України від 28 червня 1996 р. № 254к/96-ВР (у редакції від 01 січня 2020 р.) / Верховна Pада України. URL: https: / / zakon.rada. gov.ua/laws/show/254k/96-вp\#Text.

6. Про громадські об'єднання: Закон України від 22 березня 2012 р. № 4572-VI (у редакції від 28 квітня 2020 р.) / Верховна Pада України. URL: https: / / zakon. rada.gov.ua/laws/show/4572-17\#Text. 


\section{ЮРИАИЧНИЙ ВІСНИК, 2020/4}

7. Про державну реєстрацію юридичних осіб, фізичних осіб - підприємиів та громадських формувань : Закон України від 15 травня 2003 р. № 755-IV (у редакції від 16 липня 2020 р.) / Верховна Рада України. URL: https://zakon.rada.gov. ua/laws/show/755-15\#Text

8. Виборчии кодекс України : Закон України вї 19 грудня 2019 р. № 396-IX (у редакиії від 23 липня 2020 р.) / Верховна Рада України. URL: https: / / zakon. rada.gov.ua/laws/show/396-20\#Text.

9. Рішення Конституційного Суду України у справі за конституційним поданням Міністерства внутрішніх справ України щодо офіційного тлумачення положення частини першої статті 39 Конституціі України про завчасне сповіщення органів виконавчої влади чи органів місцевого самоврядування про проведення зборів, мітингів, походів $i$ демонстрацій (справа щодо завчасного сповіщення про мирні зібрання) від 19 квітня 2001 р. № 4-pn/2001. База даних «Законодавство України». URL: https: / / zakon.rada.gov. ua / laws / show / v004p710-01\#Text.

10. Івасик С.М. Живи, люби та протестуй: 28 років в очікуванні закону. Українська правда. 2019. 19 вересня. URL: https: / / www.pravda.com.ua/rus / columns / 2019/09/18/7226449/.

11. Про інформацію : Закон України від 02 жовтня 1992 р. № 2657-ХІІ (у редакиї від 16 липня 2020 р.) / Верховна Рада України. URL: https: / / zakon. rada.gov.ua/laws/show/2657-12\#Text.

12. Про доступ до публічної інформації : Закон України від 13 січня 2011 р. № 2939-VI (у редакиії від 15 серпня 2020 р.) / Верховна Рада України. URL: https: / / zakon.rada.gov.ua/laws / main/2939-17\# Text.
13. Про судоустріü $i$ cmamyc cyддів : Закон України від 02 червня 2016 р. № 1402-VIII (у редакціï від 20 червня 2020 р.) / Верховна Рада України. URL: https: / / zakon.rada.gov.ua/laws / show/1402-19\#Text.

14. Пасенюк О.М. Існуюча система судів України: конституційність та потенціал до удосконалення в ході подальшої судової реформи. Вісник Державної судової адміністрації України. 2011. № 3 (20). C. 14-18.

15. Водний кодекс України : Закон України від 06 червня 1995 р. № 213/95ВP (у редакцї від 07 червня 2020 р.) / Верховна Рада України. URL: https:// zakon.rada.gov.ua/laws/show/213/ $95-\%$ D0\% B2\% D1\%80\#Text.

16. Про внесення змін до деяких законодавчих актів України щодо забезпечення безперешкодного доступу громадян до узбережжя водних об'єктів для загального водокористування : Закон України від 29 жовтня 2019 р. № 233-IX / Верховна Рада України. URL: https://zakon.rada.gov.ua/ laws/show/233-20\#Text.

17. Державне правління: проблеми адміністративно-правової теоріі та практики / за заг.ред. В.Б. Авер'янова. Kuїв : Факт, 2003. 384 с.

18. Колпаков B.К. Адміністративне право України : підручник. Київ : Юрінком Iнтер, 1999. 736 c.

19. Адміністративне право України : підручник для юридичних вузів $i$ факультетів / Ю.П. Битяк, В.В. Богуиький, В.М. Гаращук та ін. ; за ред. Ю.П. Битяка. Харків : Право, 2001. 528 с.

20. Синявська О.Ю. Суб'єктивні публічні права приватних осіб. Право $i$ Безпека. 2010. № 2. C. 52-55. 